\title{
Subakromiyal sıkışma sendromu
}

\author{
Subacromial impingement syndrome
}

\author{
M. Hakan Özsoy ${ }^{1}$, Onur Fakıoğlu², Nevres H. Aydoğan ${ }^{1}$ \\ 1Sağlık Bakanlığı, Ankara Eğitim ve Araştırma Hastanesi, Ortopedi ve Travmatoloji Kliniği, Ankara \\ ${ }^{2}$ Sağlık Bakanlığı, Dörtyol Devlet Hastanesi, Ortopedi ve Travmatoloji Kliniği, Hatay
}

\begin{abstract}
Subakromiyal sıkışma sendromu, omuz ağrılarının en sık görülen nedenlerinden biridir. Hastalarının büyük çoğunluğunun şikayeti, özellikle baş üstü hareketlerde oluşan omuz ve kola yayılan ağrıdır. Subakromiyal sıkışma sendromu, sadece rotator manşet kaslarının akromiyon altında sıkışması sonucu değil, eksternal ve internal nedenlerin bir araya gelmesiyle oluşan kompleks bir hastalıktır. Hastalığın tanısı iyi bir anamnez ve fizik muayene ile konulabilirken, görüntüleme yöntemleri ile tanı desteklenmelidir. Fizyoterapi, ilk denenmesi gereken ve çoğunlukla hastalara faydalı olan tedavi yöntemidir. Cerrahi tedavi, fizyoterapiden fayda görmemiş ve uygun endikasyonu olan hastalara uygulanabilecek ikincil tedavi seçeneğidir. Açık ya da artroskopik subakromiyal dekompresyonda, yalnızca bursektomi ya da beraberinde akromiyoplasti başarılı sonuçlar vermektedir. İnternal sıkışma sendromu ise daha çok genç yaştaki sporcularda görülen ve postero-superior omuz ağrısı ile hastaların başvurduğu bir hastalıktır. Baş üstü zorlamalar sonucunda, tekrarlayan mikrotravmalar nedeniyle oluşan eklem yüzü rotator manşet yırtığı, labral yırtıklar, biceps tendiniti ve omuzda internal rotasyon kısıtlılığı ile kendini gösterir. Tedavisi temelde konservatiftir. Bu derleme yazısı subakromiyal sıkışma sendromu ve internal sıkışma sendromu konusunda güncel tedavi yöntemlerini özetlemeye çalışmaktadır.
\end{abstract}

Anahtar sözcükler: subakromial sıkışma sendromu; dekompresyon
Subacromial impingement syndrome is one of the most common reasons of shoulder pain. Most of the patients suffer from pain on the shoulder region extending down to the upper arm during overhead activities. The ethiology of the subacromial impingement syndrome is not only a simple mechanical impingement of the rotator cuff tendons under acromion but a complex of conditions involving a combination of intrinsic and extrinsic factors. The disease can be diagnosed with patients' history and physical examination but it should be supported with diagnostic modalities. Physiotheraphy should be the first line treatment and is effective in most of the patients. Surgical treatment is the secondary alternative in patients whose symptoms have not improved with conservative methods. Subacromial decompression with bursectomy alone or in combination with acromioplasty, gives successful results and can be performed with either open or arthroscopic techniques. Internal impingement syndrome is a disease of young and sportive population whose main symptome is postero-superior shoulder pain. This syndrome is seen in overhead thrower athlets where repeated microtraumas causes articular-sided rotator cuff tears, labral tears, biceps tendinitis, anterior instability and internal rotation deficit. The treatment is mainly non-operative. This review summarizes the current treatment alternatives of subacromial impingement and internal impingement syndromes.

Key words: subacromial impingement syndrome; decompression

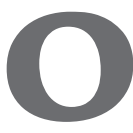
muz sıkışma sendromu ilk olarak Neer tarafindan 1972 yılında tarif edilmiştir.[1] Neer bu sendromu, rotator manşet tendonlarının akromiyonun antero-inferior kısmının altında ve omuzun öne fleksiyon ve iç rotasyon pozisyonunda mekanik olarak sıkışması şeklinde açıklamıştır. Sıkışma sendromunun klinik tanısı, sıkışma bulgusu ve sıkışma testi sonuçları ile konulabilir. ${ }^{[2]}$ Hastanın şikayetleri tipik olarak baş üstü hareketlerde ağrı (ağrılı hareket arkı) ve gece hareket sırasında ve üzerine yatarken ağrı şeklindedir. Bu şikayetler çok belirleyici olmayıp diğer omuz sorunlarında da görülebilir. Diğer yandan, özellikle genç hastalarda ve baş üstü sporlar yapan atletlerde (voleybol, tenis, yüzme gibi) sıkışma sendromu tanısı dikkatlice konulmalıdır. Bu gibi durumlarda, her ne kadar sıkışma ve subakromiyal bursit bulguları ön planda olsa da, mutlaka esas neden olabilen altta yatan glenohumeral instabilite akla gelmelidir (internal sıkışma).

- İletişim adresi: M. Hakan Özsoy, Sağlık Bakanlığı, Ankara Eğitim ve Araştırma Hastanesi, 1. Ortopedi ve Travmatoloji Kliniği, Ulucanlar, Ankara Tel: 0532 - 4247339 e-posta: hakanozsoy@rocketmail.com

- Geliş tarihi: 22 Ağustos 2013 Kabul tarihi: 25 Ekim 2013 


\section{SUBAKROMIYAL SIKIŞMA SENDROMU}

Subakromiyal sıkışma sendromu (SSS) omuz ağrılarının en sık nedenlerinden biridir. ${ }^{[3]}$ SSS ile ilişkili omuz ağrıları, subakromiyal bursit gibi basit patolojilerden rotator manşet tendinopatilerine ve tam kat yırtıklarına kadar çeşitlilik gösteren bir aralığa sahiptir.

\section{Anatomi}

Subakromiyal boşluk, inferiorda humerus başı ve tüberkülüm majus, superiorda ise akromiyon (akromiyonun aneterior 1/3'lük bölümü), korakoakromiyal bağ, korakoid çıkıntı ve daha posteriorda yerleşen akromiyoklaviküler eklem ve akromiyoklaviküler ligament ile sınırlandırılan bölgedir (Şekil 1). Bu alandan rotator manşet kasları geçer ve içinde hareket eder. Omuz $0^{\circ}$ abduksiyonda iken çekilen AP grafilerde akromiyon ile humeral başı arası mesafe ortalama $1,1 \mathrm{~cm}$ 'dir (1,0-1,5 cm). Bu iki yapı arasında kalan rotator manşet (çoğunlukla supraspinatus tendonu), biseps kasının uzun başı, bursa ve korakoakromiyal ligament bulunur. Bahsedilen kemik yapılar arasında uyumsuzluk gözlendiğinde subakromiyal yapılarda sıkışmaya neden olur.

Omuzun stabilitesi temelde kaslar tarafindan sağlanır. Statik stabilizatörler; eklem anatomisi, glenoid labrum, eklem kapsülü, glenohumeral bağlar ve negatif eklem basıncıdır. Daha önemli olan dinamik stabilizatörler ise, rotator manşet kasları, bisepsin uzun başı, skapulotorasik hareket ve diğer omuz çevresi kaslardır (pectoralis major, latissimus dorsi ve serratus anterior). Rotator manşet kasları omuzun üç temel hareketinden sorumludur: abduksiyon, internal rotasyon ve eksternal rotasyon. Supraspinatus kası abduksiyonu başlatmada, infraspinatus ve teres minor eksternal rotasyonda ve subskapularis internal rotasyonda görev yaparlar. Rotator manşet kasları omuz abduksiyon gücünün \%45'inden ve eksternal rotasyon gücünün \%90'ından sorumludur. ${ }^{[4]}$ Diğer yandan, rotator manşet kasları, humerus başının glenoid fossa içinde dinamik stabilizasyonunu sağlar ve deltoidin humerusu eleve eden gücüne karşı humerus başını mediale geloide doğru bastırarak "güç çifti”" oluşturur (Şekil 2). Rotator manşetteki yırtıklar sonucunda deltoidin gücüne karşı konulamadığı için, humerus başında proksimal migrasyon ve dolayısıyla subakromiyal sıkışma görülür.

\section{Etiyoloji}

SSS subakromiyal boşluğun daralması sonucunda subakromiyal yapılarda görülen zedelenmedir. Bu patolojinin oluşumunda birçok mekanizma öne sürülmüştür. Bunlar, internal ya da intratendinöz (tendonun kendi içindeki patolojilerden kaynaklanan) nedenler ve eksternal ya da ekstratendinöz (tendonun çevresindeki dokulardaki patolojilerden kaynaklanan) nedenler olarak iki ana grupta incelenebilir. ${ }^{[3]}$ Sıklıkla, patoloji bahsedilen etiyolojik faktörlerin kombinasyonu ile oluşmaktadır.

\section{Eksternal nedenler}

Eksternal nedenler arasında, subakromiyal bölgeyi daraltan nedenler olan akromiyonun morfolojik yapısı

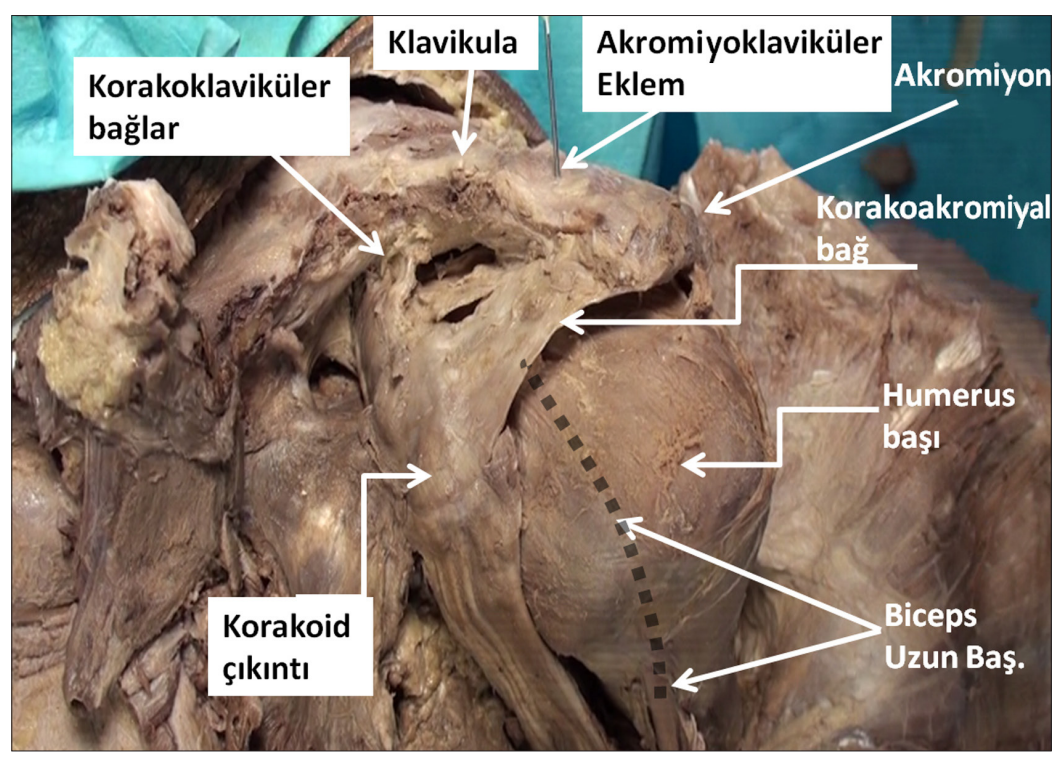

Şekil 1. Sol omuz anterior görünüm. Subakromiyal boşluk ve çevresindeki anatomik yapılar görülmekte.

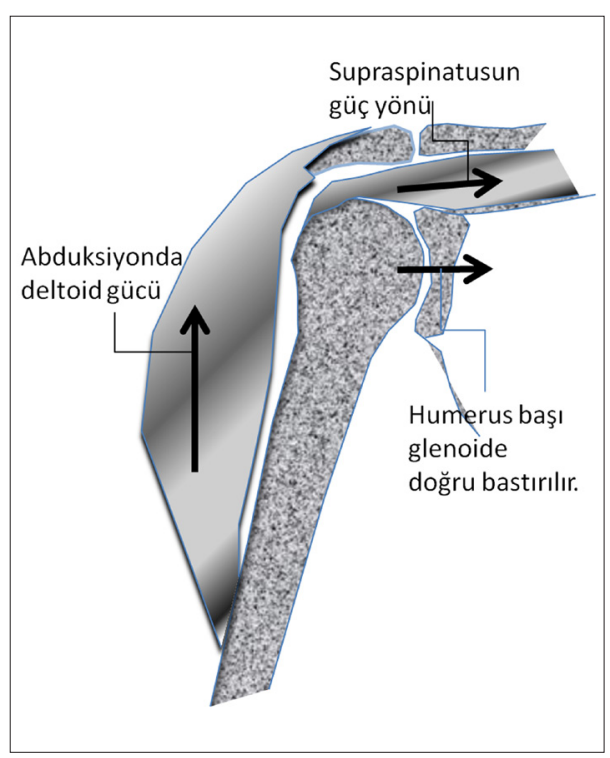

Şekil 2. Deltoid ve supraspinatus kasının oluşturduğu "güç çifti". 
(eğik-çengel şekilde akromiyon), akromiyon ve tuberkulum majusun maluniounları, os akromiyale, akromiyoklaviküler eklem patolojileri ve instabiliteleri en önde gelenlerdir. ${ }^{[5]}$ ilk hipotezler, sıkışmanın abduksiyonun orta seansında, lateral akromiyonla rotator manşet arasında olduğunu öne sürmekteydi ve lateral akromiyonektomiye kadar uzanan tedaviler uygulanmaktaydı. ${ }^{[6]}$ Ancak Neer ${ }^{[1]}$ yaptığı kadavra çalışmalarıyla, anterior akromiyonda çıkıntı ve fazlalıkların varlığını göstererek, bu yapıların rotator manşette sıkışmaya neden olarak, patolojilerin lateralden değil anterior akromiyondan kaynaklandığını belirtmiştir ve tedavi olarak anterior akromiyoplastiyi önermiştir. Neer, ${ }^{[2]}$ subakromiyal sıkışmanın üç evresi olduğunu açıklamıştır. Evre 1, daha çok 25 yaş altı genç hastalarda görülen akut inflamasyon, ödem ve rotator manşetin hemorajik patolojisinin gözlendiği durumdur. Bu evre genellikle konservatif tedaviye cevap alınan evredir. Evre 2, 25-40 yaş arasında ödem ve inflamasyonun fibrozis ve rotator manşet tendinitine ilerlediği zamandır. Bu evrede, rotator manşette parsiyel yırtıklar görülebilmektedir. Evre 3'te ise, rotator manşette tendon yırtıkları, korakoakromiyal arkta osteoartritik değişiklikler belirir. Genellikle 40 yaş üstünde gözlenen bu evre, anterior akromiyoplasti ve rotator manşet onarımı gibi cerrahi prosedürlerle tedavi edilebilmektedir.

Akromiyonun değiş̧ik morfolojik özelliklerini ele alan Bigliani ve ark. ${ }^{[7]}$, üç değişik tipin var olduğunu göstermişlerdir: Tip 1, düz; Tip 2, anteriora eğimli; Tip 3, çengel veya kanca şeklinde. Bu akromiyon tipleri skapula-Y (skapula çıkım - skapula outlet) grafisinde görülebilir (Şekil 8). Aşağı doğru kanca gibi dönük olan ve subakromiyal bölgeyi daraltan Tip 3 akromiyonun, özellikle rotator manşet dejenerasyonu ve yırtıkları ile daha sık görüldüŭgü gösterilmiş̧tir. ${ }^{[8,9]}$ Akromiyoklaviküler eklemde hipertrofi ve inferiora doğru çıkıntılar da subakromiyal böldeyi daraltan kemik patolojiler arasındadır. Diğer yandan hipertrofiye ya da daha ileri seviyelerde kalsifiye olmuş korakoakromiyal ligament de sıkışmaya neden olmaktadır. ${ }^{[1]}$ Yakın dönemde yapılan kadavra çalışmalarında, normal durumlarda bile korakoakromiyal bağın omuzun tüm hareketlerinde rotator manşet ile temas halinde olduğu ve bunun da korakoakromiyal ligament bükülmesine ve tekrarlayıcı subakromiyal temasına yol açarak, akromiyal çıkıntıların oluşumu dahil olmak üzere dejeneratif değişikliklerin başlamasına neden olabileceği iddia edilmiştir. ${ }^{[10,11]}$ Glenohumeral eklem instabilitesi olan olgularda omuz seviyesi üzerindeki aşırı abduksiyon gibi hareketlerde SSS görülebilir.

\section{internal nedenler}

Burada kabul edilen temel neden rotator manşetteki azalmış damarlanma ve kanlanmadır. Özellikle ileri yaş grubu hastalarda, azalmış vaskülarite ile birlikte tekrarlayıcı tensil güçler rotator manşet patolojilerini oluşturur. Önce parsiyel başlayan yırtıklar zaman içinde tam kat yırtıklar haline dönüşebilirler. ${ }^{[12]}$ Hipovasküler alanın omuz hareketleri ile akromiyon ve korakoakromiyal bağa tekrarlayan teması, diğer öne sürülen mekanizmadır. Burada, akromiyondaki hipertrofi ve spur oluşumu ya da Tip 3 akromiyon benzeri şekil bozuklukları, tendon üzerinde daha fazla temasa ve yırtığa yol açabilmektedir. ${ }^{[13]}$ Diğer yandan, rotator manşetteki dejenerasyon nedeniyle oluşan güç kaybının supraspinatusu zayıflatarak humerus başının glenoid üzerinde merkezleyemediği ve dolayısıyla humerus başının, deltoid kas hakimiyetini artması ile, superiora doğru migre olarak subakromiyal boşluğu daralttığı ve sıkışmaya yol açtığı da öne sürülmektedir. Bu şekilde daralan alanda ikincil olarak, SSS ile birliktelik gösteren akromiyonun osteofitik çıkıntıları ve erozyonlarla eşlik eden patolojiler oluşabildiği de kabul edilmektedir. Diğer yandan kalsifik tendinit de tendon içinde dejenerasyon ve şişmeye neden olarak subakromiyal sıkışmaya ve dolayısıyla da manşet yetmezliğine neden olabilmektedir. ${ }^{[14]}$

\section{Tanı}

Bu patolojinin teşhisi için; iyi alınmış bir anamnez, hastanın şikayetlerine yönelik yapılan tam bir fizik muayene ve son olarak da bunları tamamlayıcı görüntüleme yöntemleri gerekmektedir.

\section{Klinik ve anamnez}

Hastaların çoğunluğunun 40 yaş ve üzerinde olduğu subakromiyal sıkışma sendromunda, ağrının yerleşiminin tipik olarak anterolateral akromiyonda olduğu ve lateralden humerusun orta bölümüne kadar uzanmakta olduğu gözlenmektedir. Subakromiyal bursanın lateralde deltoid yapışma yerine kadar uzanması, sıkışma ve bursit varlığında ağrının lateralde hissedilmesinin en önemli nedenidir. Bu ağrının hastaya gece, özellikle patolojinin var olduğu omuz üstüne yattığı veya yüklendiği esnada artması ve gün içerisinde özellikle baş üstü hareket ve egzersizlerle varlık göstermesi de SSS için birer işarettir. Sorulması gereken bir diğer soru, omuz üzerine alınan bir travmanın olup olmadığıdır. Nitekim sıkışma semptomları, maruz kalınan travma sonrası haftalar ve aylar içerisinde kendini gösterebilmektedir. Tüm bunların yanı sıra, gündelik saç tarama veya diş firçalama gibi kolun baş hizası veya üstüne gitmesi gereken rutin işlerde ağrı duyulması ve buna istinaden kullanmamaya bağlı omuzda ileri dönemde güçsüzlük, kas atrofisi ve hatta kronik zeminde meydana gelebilecek rotator manşet yırtıklarına bağlı semptomlar da göz ardı edilmemelidir. 


\section{Fizik muayene}

Sıkışma semptomlarıyla gelen hastanın ayırıcı tanısı da düşünülerek, fizik muayene içerisine ağrının kaynaklanabileceği omuz dışında baş ve boyun da dahil edilmelidir. Fizik muayene, omuzun hareket açıkığını, rotator manşetin gücünü ve semptomları ortaya çıkaracak provokatif testleri içermelidir. Günümüzde sıklıkla kullanılan testler, Neer ve Hawkins testleridir. Ancak bu testler, SSS için oldukça hassas iken, buna özgül (spesifik) değildir. ${ }^{[15,16]}$ Her iki testin amacı da manevralarla supraspinatus ile akromiyon arasındaki mesafeyi azaltarak subakromiyal bölgede darlık yaratmaktır. Neer testi veya işareti (Şekil 3) olarak adlandırılan muayenede, skapula muayene edenin eliyle stabilize edilir ve omuz, pasif olarak maksimum fleksiyona getirilir. Ağrı duyulması testin pozitifliğini gösterir. ${ }^{[2]}$ Bu testte amaç supraspinatusun korakoakromiyal bağ ve anterior akromiyon altında sıkışmasıdır. Hawkins testinde (Şekil 4) ise omuzun pasif bir şekilde öne doğru $90^{\circ}$ 'lik elevasyonu sonrası maksimum iç rotasyon yaptırılarak

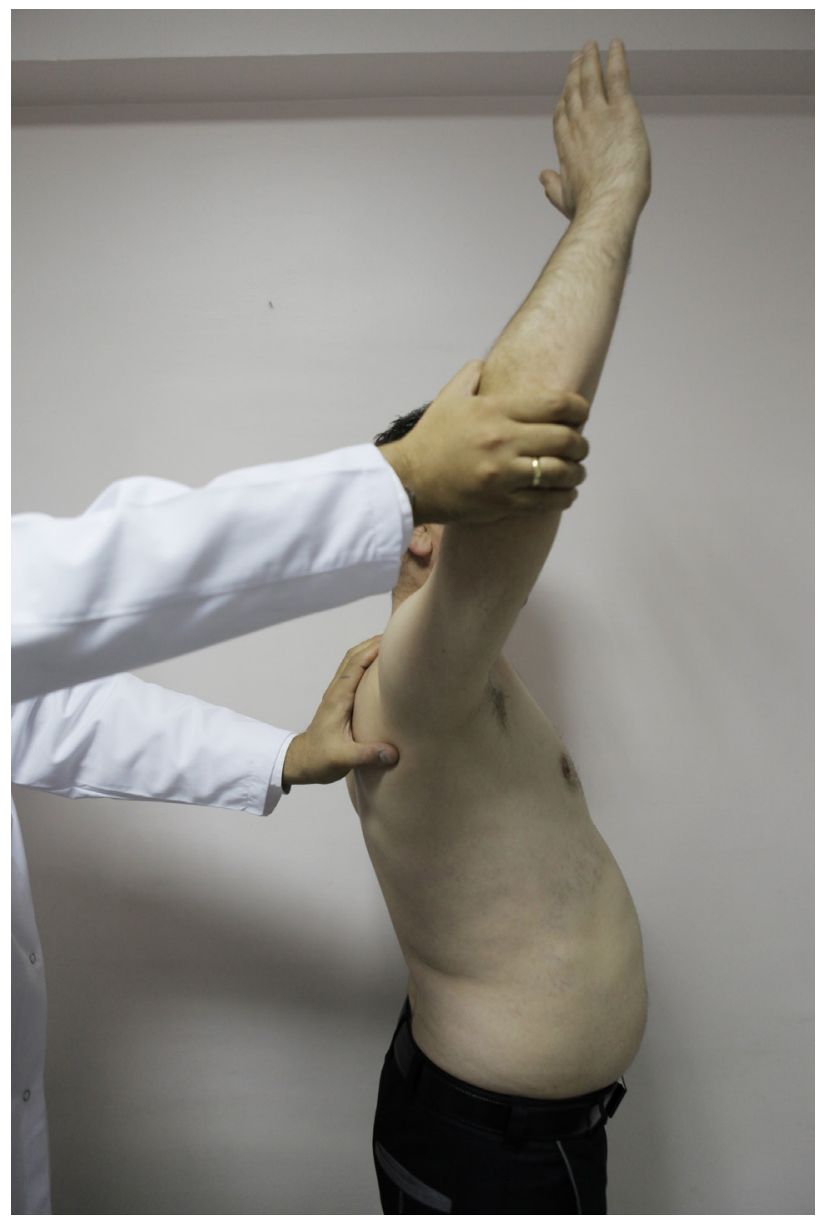

Şekil 3. Neer muayene testi. Skapula muayene edenin eliyle stabilize edilir ve omuz, pasif olarak maksimum fleksiyona getirilir. ağrının varlığı sorgulanmaktadır. ${ }^{[17]}$ Yapılan çalışmalarda rotator manşetin akromiyona omuz $90^{\circ}$ ' de iken daha yakın olduğu gözlenmiş, yani Hawkins testinin Neer işaretine göre daha fazla subakromiyal daralmaya yol açtığı belirtilmiştir. ${ }^{[18,19]}$ Bunların yanı sıra, Neer'in sıkışma testi invaziv bir yöntem olup $10 \mathrm{ml}$ 'lik lokal anestetik ajanın subakromiyal bölgeye enjekte edildikten sonra provokatif manevralar sonucu var olan ağrının yok olması ile seyreder (Şekil 5. a-c). ${ }^{[2]} \mathrm{Bu}$ testin pozitifliği, subakromiyal dekompresyonun sonucunun büyük oranda başarılı olabileceği gösterir.[20,21] Subskapularis kasına özgü bele götürülen hasta elinin muayene eden kişinin elini itmesi ile uygulanan lift-off testi uygulanabilir. SSS'te, özelikle ağrılı olan supraspinatus kası için hastanın her iki omuzu $90^{\circ}$ abduksiyon ve $30^{\circ}$ öne doğru fleksiyonda iken, başparmakların zemini gösterecek şekilde iç rotasyon yapması ardından, kollara muayene eden kişi tarafından baskı uygulanır ve hastaya karşı gelmesi söylenir (Şekil 6). Her iki testte de ağrı görülmesi, SSS ile birliktelik gösterebilecek rotator manşet patolojilerine işaret edebilir.

\section{Görüntüleme}

Görüntüleme yöntemi olarak, skapular planda AP (gerçek AP), aksiller ve supraspinatus çııım (outlet) grafileri hastalığın ve altta yatan patolojilerin tanısının konmasında yardımcıdır. AP grafide akromiyo-humeral mesafe, tüberkulum majusta subkondral kistler ve skleroz, akromiyonun anteriorunda skleroz ve spur oluşumu dikkat edilmesi gereken bulgulardır. Özellikle akromiyo-humeral mesafenin $7 \mathrm{~mm}$ 'nin altında düşmesi rotator manşet yırtığını düşündürür. Skapula çıkım grafisinde özellikle akromiyondaki deformite ve akromiyon tipleri değerlendirilebilir (Şekil 7 ve 8). Diğer yandan, $20^{\circ}$ kaudo-kranial açıla çekilen gerçek

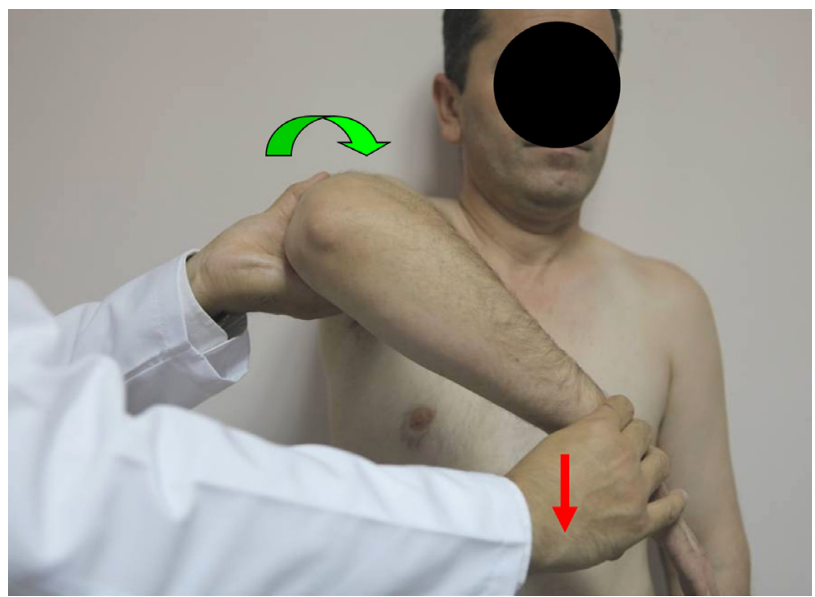

Şekil 4. Hawkins testi. 

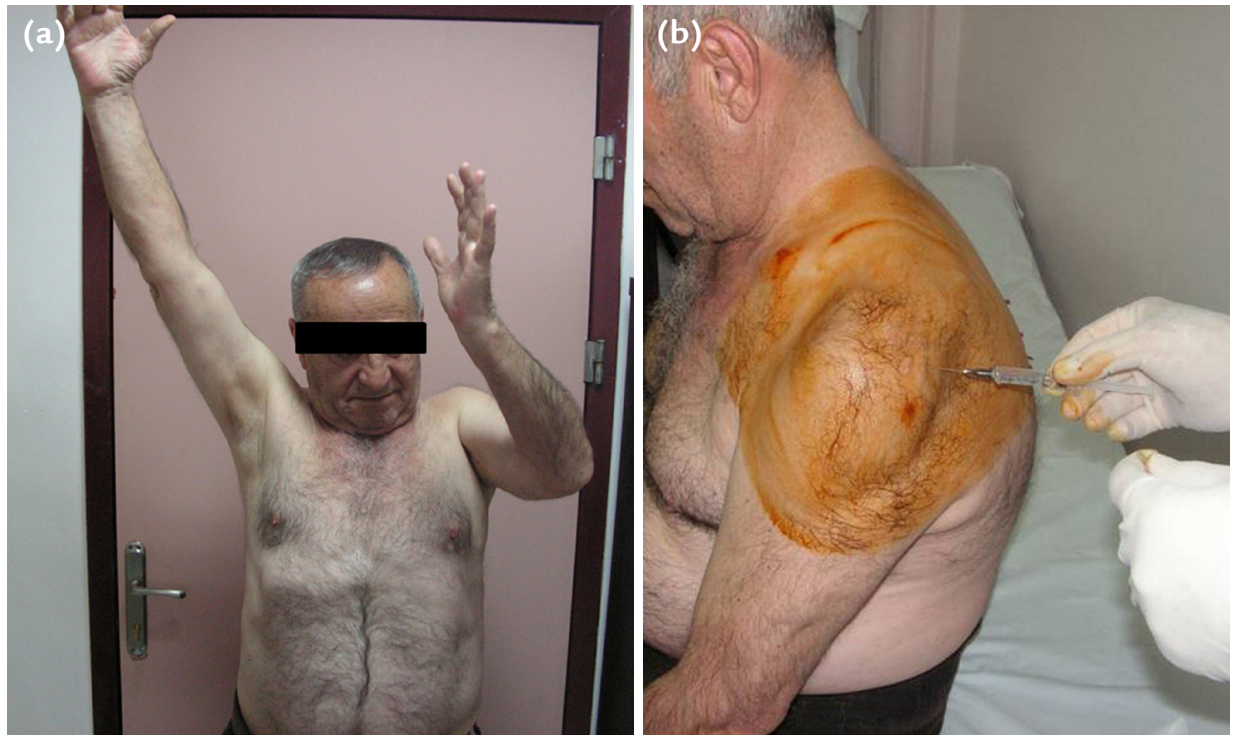

Şekil 5. a-c. Sol omuz sıkışma sendromu. Omuz abduksiyon ve fleksiyonunda kısıtılığın (a), lokal anestetik enjeksiyonu (b) sonrasında düzeldiği (c) görülmekte.

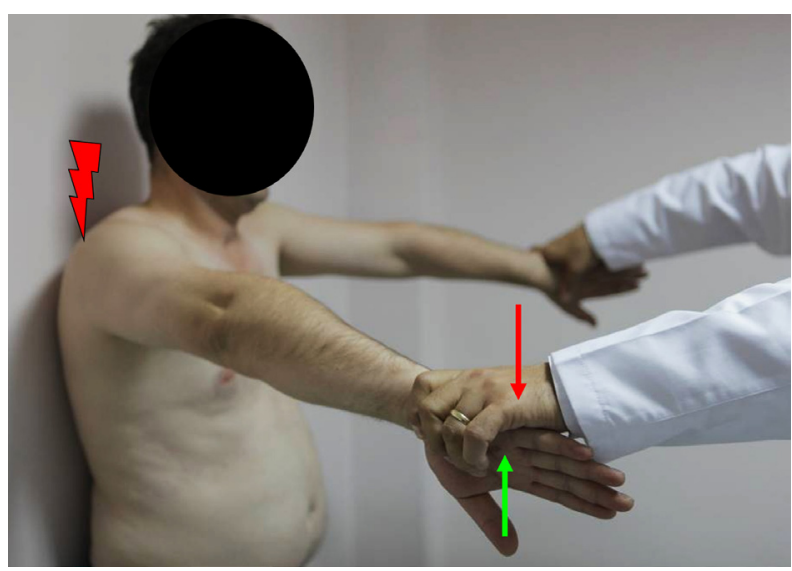

Şekil 6. Supraspinatus kas muayenesi. Hastanın her iki omzu $90^{\circ}$ abduksiyon ve $30^{\circ}$ öne doğru fleksiyonda iken başparmakların zemini gösterecek şekilde iç rotasyon yapması ardından kollara muayene eden kişi tarafından baskı uygulanır ve hastaya karşı gelmesi söylenir. Ağrı olması ve diğer tarafa göre gücün az olması, pozitif test anlamına gelir.

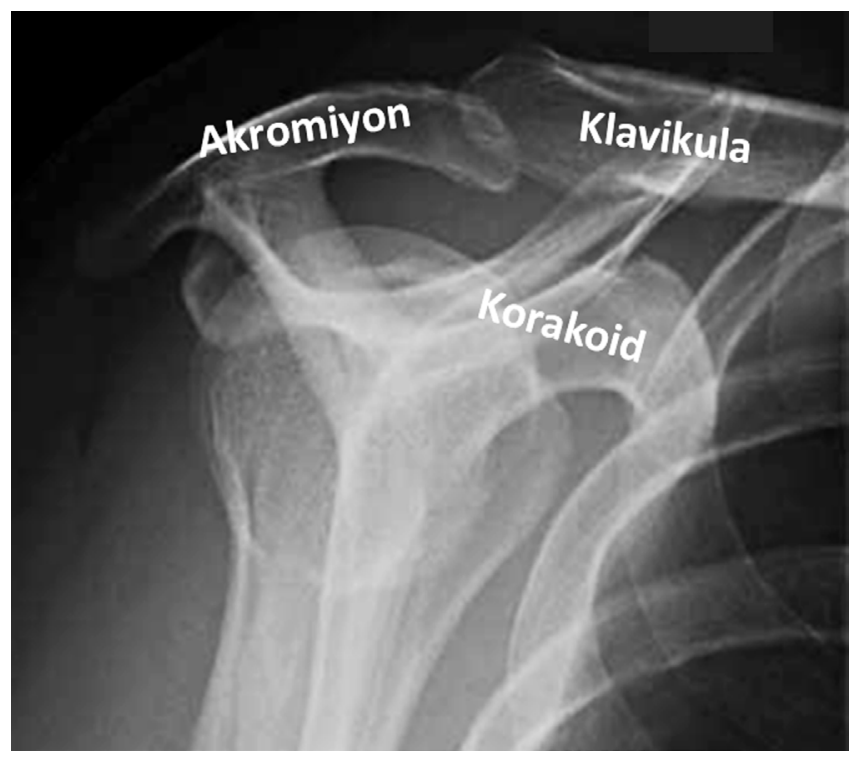

Şekil 7. Skapula çıkım (outlet) grafisi.
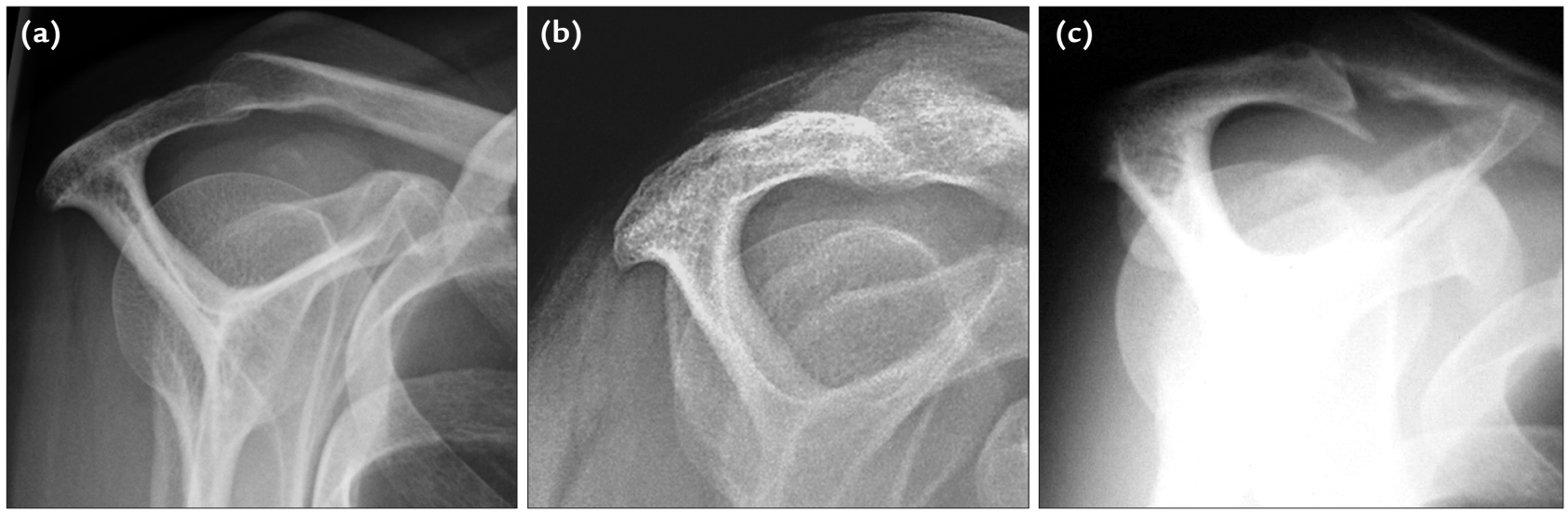

Şekil 8. a-c. Bigliani ve ark.'na göre akromiyon tipleri. Tip 1 (a) düz, Tip 2 (b) eğik ve Tip 3 (c) kanca şeklinde akromiyon. 
omuz AP grafisinde (Zanca grafisi) akromiyoklaviküler eklem patolojileri daha detaylı görülebilir. Aksiller grafide os-akromiale varlığına dikkat edilmelidir. MR görüntülemede yumuşak dokulara ait patolojiler daha detaylı görülür. Özellikle tendinit, bursit, biseps tendonu patolojileri, kas atrofisi, akromiyoklaviküler eklem patolojileri ve akromiyon tipi konusunda bilgi verir. Özellikle rotator manşette parsiyel ya da tam kat yırtık varlığını göstermede yardımcıdır. MR görüntüleme SSS'de ayrımı zor olan ve sekonder sıkışma sendromu nedenleri arsındaki korakoakromiyal bağ ossifikasyonu ile subakromiyal spur varlığını sagittal oblik planda en iyi şekilde gösterir. Noninvazif bir metot olması, radyasyon içermemesi, patolojinin hangi evrede olduğu hakkında bilgi verebilmesi ve gerektiğinde eklem içi kontrast madde verilerek tanısı zor patolojileri tanımlaması açısından, MR avantajlı bir yöntemdir. SSS'ye eşlik eden subdeltoid bursit ile beraber kronik zeminde oluşabilecek rotator manşet yırtıklarının değerlendirilmesinde de MR önemli bir seçenektir.

\section{Tedavi}

Sıkışma sendromu için tedaviyi konservatif ve cerrahi olarak ikiye ayırabiliriz. Daha sıklıkla tercih edilen konservatif tedavi içerisine, medikasyon, fizyoterapi ve şok dalga terapisi girerken, cerrahi tedavide açık veya artroskopik olarak yapılan subakromiyal dekompresyon bulunmaktadır. Tedavi seçenekleri arasında yeralan şok dalga tedavisi veya ultrason tedavisinin etkinliğinin düşük olduğu gösterilmiştir. ${ }^{[22-24]}$ SSS'nin ilk tedavisi fizyoterapidir. Son yıllarda yapılan ve randomize kontrollü çalışmaların bir arada değerlendirildiği literatür derleme çalışmalarında, fizyoterapi ve cerrahi uygulanan hastaların sonuçları arasında anlamlı bir fark görülmezken, hastaların cerrahi tedavi öncesi mutlak fizyoterapi görmesi ve doğru endikasyon ile cerrahinin uygulanması gerektiği bildirilmektedir. ${ }^{[25-27]}$ Rehabilitasyon programı, akut fazda hastanın ağrısının, inflamasyonun gerilemesini, kas atrofisini engellemeyi, ağrısız ROM'un geri kazanılmasını ve omuz artrokinematiğinin normale dönmesini amaçlamaktadır. $\mathrm{Bu}$ fazda, aktif periyodik dinlenme ve ağrıyı arttıran aktivitelerden uzak durmak istenirken, pandüler omuz egzersizleri, iç ve dış omuz rotator kasları, biseps, deltoid ve bunun yanı sıra skapuler stabilize edici kasları güçlendirme egzersizleri önerilmektedir. Akut aşamada başarı sağlanırsa, rehabilitasyonun geri dönüş fazına geçilir ve bu evrede ROM'un tam anlamıla geri kazanılması, semptomsuz günlük yaşama dönülmesi ve nöromusküler gücün geliştirilmesi hedeflenir. Pasif pandüler egzersizlerin yerini, tüm düzlemlerde yapılacak aktif egzersizler ve germe egzersizleri alır. Güçlendirme, omuz iç ve dış rotatorlarının ağırlığa karşı gelerek izotonik şekilde ekstansiyona, horizontal abduksiyona, $90^{\circ}$ fleksiyona ve $90^{\circ}$ abduksiyona zorlanmasıyla yapılır. Hareketleri daha da ilerletmek için, ağrısız bir ROM'a sahip olunması ve sağlam tarafla yapılan manuel kas testinde \%70 güç gözlenmesi gerekmektedir. Fizyoterapinin sadece egzersiz ile fizyoterapist eşliğinde yapılması ortalama düzeyde bir ağrı değişimi yaparken, fizyoterapi ile manuel tedavinin birlikteliğinde daha belirgin bir şekilde ağrııı ve fonksiyonel kaybın geriye dönddüğü gözlenmiştir. ${ }^{[28-29]}$ Codsi'nin yaptığı çalışmada ${ }^{[30]}$ steroid enjeksiyonun, hiçbir zaman tek başına bir SSS tedavisi olmadığı, hastanın ya ilk gelişinde yapılacak olan fizyoterapide ağrı eşiğini düşürme amaçlı ya da altı haftalık fizyoterapi sonrası ağrı düzeyinde değişiklik olmayan hastalara uygulanması gerektiği kanıtlanmıştır.

Subakromiyal steroid enjeksiyonu da SSS tedavisinde kabul edilen ve yaygın uygulanan bir tedavi yöntemidir. Lokal anestetik ile birlikte yapılan bu enjeksiyonlar, hastalığın tanısı, tedavisi ve hem de uygulanabilecek cerrahi tedavinin prognozu hakkında fikir vermesi açısından önem taşımaktadır. ${ }^{[31,32]}$ Diğer yandan yakın dönemde yapılan bir randomize kontrollü çalışmada, steroid enjeksiyonunun 6 haftalık takipte tenoksikam enjeksiyonuna göre daha başarılı olabildiği gösterilmiştir. ${ }^{[32]}$ Steroid enjeksiyonunun yanı sıra, subakromiyal bölgeye disodyum EDTA enjeksiyonlarının da SSS tedavisinde etkili olduğu kabul edilmektedir. ${ }^{[33]}$

Cerrahi tedavi, 3-6 aylık konservatif tedaviye cevap vermeyen hastalara önerilmektedir. Neer ${ }^{[5]}$ anterior açık akromiyoplastide, rotator manşete sürttüğünü iddia ettiği anterior akromiyon kenarının ve korakoakromiyal bağın uzaklaştırılması gerektiğini belirtmiştir. Bu tekniğin uygulandığı olgularda, uzun dönem takipte başarılı sonuçlar elde edilmiştir. ${ }^{[34]}$

Cerrahi tedavi özellikle omuzda hareket kısıtlılığı olmayan, lidokain enjeksiyonu sonrası ağrısında azalma gözlenen, Tip 3 akromiyonu bulunan ve MRG'de rotator manşette değişiklikler görülen hastalarda daha başarılı olmaktadır. ${ }^{[14]}$ Ameliyat öncesi Neer ve Hawkins testlerinin pozitif olmasının da cerrahinin başarısını öngörmek açısından önemli olduğu belirtilmektedir. ${ }^{[35]}$ Artroskopik dekompresyon, hastaların daha çabuk işe dönmesi, daha az hastanede yatış süresi ve kozmetik görüntü açısından üstünlük sağlaması nedenleriyle, günümüzde daha sık kullanılmaktadır (Şekil 9). Artroskopik teknik, sıkışma sendromunda var olan korakoakromiyal ark abrazyonunun direkt görünmesini sağlarken, cerrahın sıkışmaya neden olan yapılara müdahale etmesini kolaylaştırır. Odenbring'in yaptığı karşılaştırmalı çalışmada[36], artroskopik dekompresyonun açık cerrahiye karşı uzun dönem izlemde klinik açıdan da üstün olduğu belirtilmiştir. Magaji ve ark.'nın yaptığı çalışmada ${ }^{[37]}$, artroskopik 


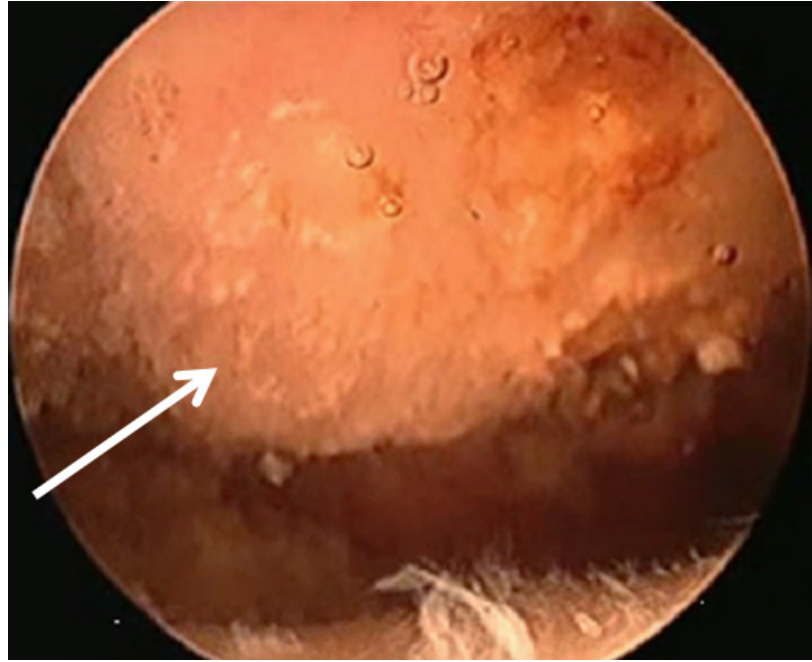

Şekil 9. Sağ omuz, posterior portalden görünüm. Anterior akromiyon altında düzensizlik ve akromiyonda inferior doğru çıkıntı (beyaz ok) görülmektedir.

subakromiyal dekompresyon yapılacak hasta seçiminde klinik ve radyolojik olmak üzere dört adet kriterin olması halinde bu ameliyatın daha etkili olduğu gözlenmiştir. Bu kriterler, steroid enjeksiyonundan geçici fayda gören hastalar ve abduksiyonun orta sekansında ağrı duyan, pozitif Hawkins testi ile sıkışmanın radyolojik olarak kesin bulgularına sahip hastalar olarak sıralanabilir. Artroskopik subakromiyal dekompresyonun uzun dönem izlemde de etkisinin devam ettiği ve başarılı olduğu yakın dönemde yapılan hasta serilerinde gösterilmiştir. ${ }^{[38]}$ Bu cerrahi yöntemin, orta ve ileri yaş grubunda başarılı olsa da, özellikle ileri yaş grubundaki hastalarda (57 yaş ve üzeri) fizyoterapiye kıyasla daha başarılı olduğu gösterilmiştir. ${ }^{[39]}$

Subakromiyal dekompresyonda tartışılan ve üzerinde tam olarak fikir birliğine varılamayan bir konu da hastaya sadece bursektomi mi, yoksa bursektomi ile birlikte akromiyoplasti de yapılmasının gerekli olduğudur. Özellikle son yıllarda rotator manşet cerrahisi yapılan hastalarda, sadece bursektomi yapılması gerektiğini savunan yazarlar bulunmaktadır. ${ }^{[40,41]}$ Teorik olarak, akromiyoplasti yapılmayan girişimlerde korakoakromiyal arkın korunduğu bilinmektedir ve humerus başının sekonder stabilizatörü olan korakoakromiyal ligament ve akromiyon antero-superiora doğru migrasyonu önlenmektedir. ${ }^{[42]}$ Yakın dönemde yapılan bir sistematik gözden geçirme çalışması, ${ }^{[43]}$ bu konuda yapılmış altı randomize kontrollü çalışmayı içermektedir. Bu çalışma sonuçları -kesin olmamakla birliktesadece bursektomoninin, bursektomi ile birlikte akromiyoplasti yapılan hastalar kadar başarılı olabildiğini göstermiştir. Bu çalışmalar ışığında, akromiyonun tam

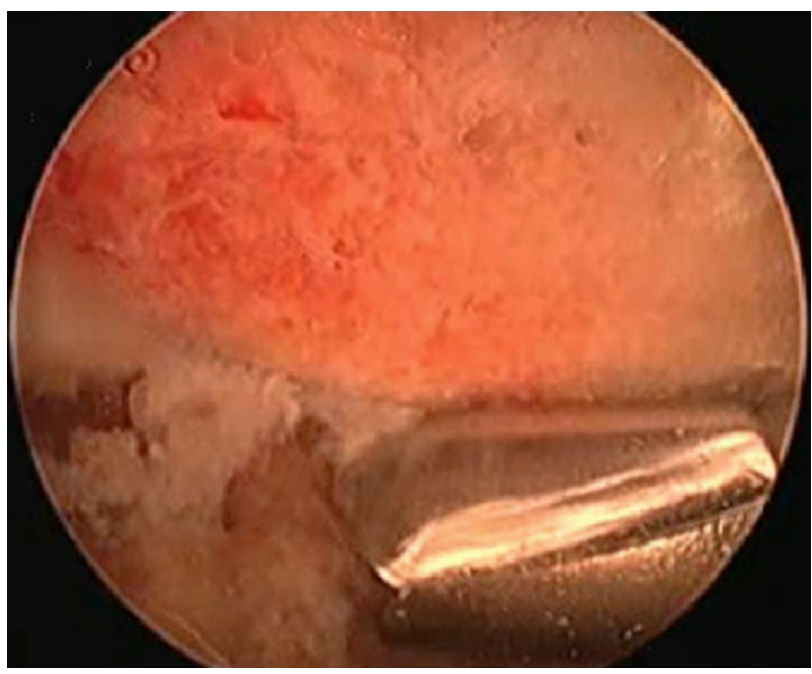

Şekil 10. Sağ omuz, posterior portalden görünüm. Burr ile akromiyoplasti sonrası düz yüzey elde edilmiştir.

olarak düz hale getirildiği agresif bir akromiyoplasti yerine, sadece anteriordaki patolojik temasa neden olan çıkıntıların tıraşlanmasının yeterli olabileceği söylenebilir (Şekil 10).

Artroskopik subakromiyal dekompresyonda ne kadar kemik keserek çıkartılması gerektiği de bir diğer tartışma konusudur. Levy ve ark., ${ }^{[44]}$ korakoakromiyal bağın rejenere olabildiğini belirtmişlerdir. Hunt ve ark. [45] da artroskopik akromiyoplasti sonrası korakoakromiyal bağ, periost ve deltoid kas yapışmasını içeren bir yapının, incelse de sağlam olarak varlığını sürdürebildiğini göstermişlerdir. Buna karşın Green ve ark. ${ }^{[46]}$ yaptıkları kadavra çalışmasında, $4 \mathrm{~mm}$ akromiyon rezeksiyonu sonrasında deltoid yapışmasının $\% 55^{\prime}$ inin, $5,5 \mathrm{~mm}$ rezeksiyon sonrası ise \%77'sinin devamlılığının kaybolduğu gösterilmiştir. Sadece bursektominin başarılı sonuçlarını bildiren çalışmalar da dikkate alındığında, kontrollü ve agresif olmayan bir akromiyoplastinin yeterli olacağı söylenebilir (Şekil 11).

Ancak artroskopik teknik için aynı zamanda cerrahın tecrübesi de önemli yer tutmaktadır. Zira, artroskopik olarak yapılan subakromiyal dekompresyondan fayda görmeyen hastalara sonraki seansta yapılan açık akromiyoplasti ardından düzelme gözlendiği belirtilmiştir. ${ }^{[47]}$

Akromiyoplasti sonrası erken dönemde hastanın kendini iyi hissetmesi için kol boyun askısı verilebilir. Sonrasında, en kısa zamanda terk edilmeli ve daha önceki rehabilitasyon fazlarında tanımlandığı gibi aktif pasif ROM egzersizlerine başlanmalıdır. Hastanın subjektif sempomları azalınca günlük normal aktivitelerine, 


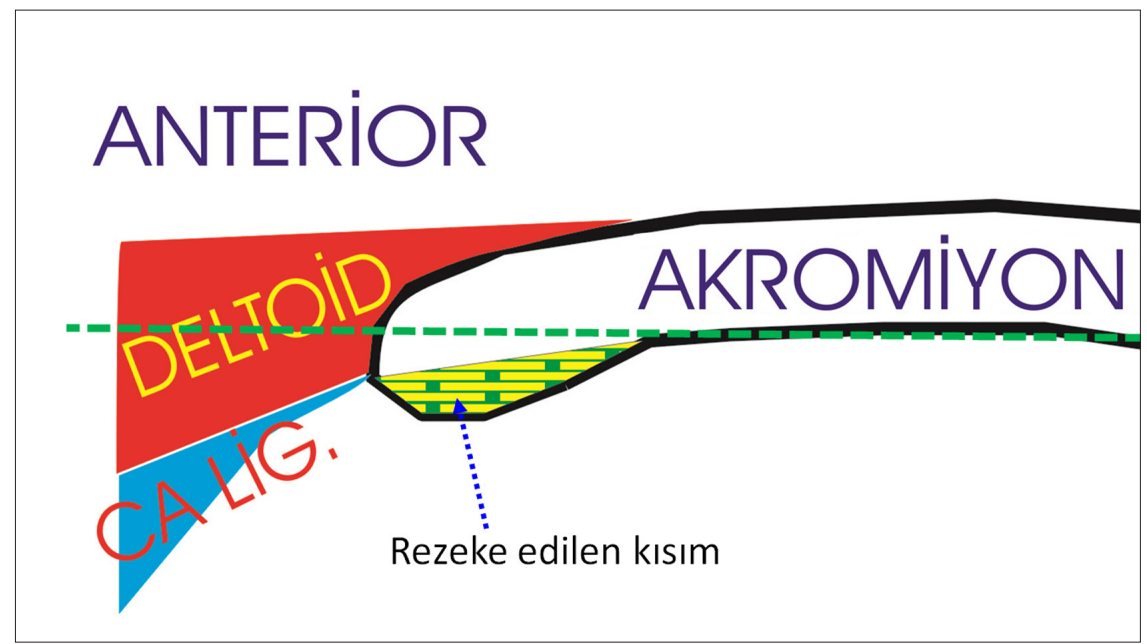

Şekil 11. Sınırlı anterior akromiyoplasti (taralı alan) sonrası korakoakromiyal bağ (CA Lig.) ve deltoid yapışması kısmen de olsa korunabilmektedir. Kesik çizgi klasik akromiyoplasti hattını göstermektedir ve rezeke ettiği miktar fazladır.

3-4 ay sonrasında ise aktif spor yaşamına dönmesi uygun bulunmaktadır.

\section{INTERNAL SIKIŞMA SENDROMU (ISS)}

Sıkışma sendromu alt başlığında incelenen ISS; omuz ağrısı şikayeti olan genç ve sporcu yaş grubunda sıklıkla karşımıza çıkar. Bu konudaki inceleme ve değerlendirmeler oldukça fazladır. Özellikle beyzbol sporunda firlatma mekanizması nedeniyle ayrıntılı çalışmaların yapıldığını söyleyebiliriz. Bennet ${ }^{[48]} 1959$ 'da, kolunu baş seviyesi üzerinde kullanan, posterior omuz ağrısı olan sporcuda posterior omuz kapsülünde inflamasyon olarak tanımladığı patoloji ile ilgili, kendi adı ile anılan glenoid postero-infreriorunda egzostozu radyolojik olarak tanımlamıştır. Lombardo ve ark. ${ }^{[49]} 1977$ 'de, açık yaklaşımla tedavi ettikleri hastalarda posterior omuz kapsülü ve çevresi yumuşak dokulardaki fibrotik değişiklikleri göstermişlerdir. Andrews ve ark. ${ }^{[50]}$ ise 1985 'te, omuzdaki hasarın tekrarlayan firlatma hareketleri sonrası olduğunu belirtmişlerdir.

$J^{\prime}{ }^{[51]} 1989$ 'da, postero-superior omuz ağrısı ile anterior instabilitenin birlikte olduğunu tespit etmiştir. Jobe ve ark. ${ }^{[52]}$ subakromiyal dekompresyonla posterior omuz ağrıları düzelmeyen sporcularda kapsüler gevşeme sonucu anterior instabilitenin etkisinin olduğunu belirtmişlerdir. Walch 1991 'de, ${ }^{[53]}$ glenoid posterosuperior karşısına gelen supraspinatus tendonu eklem yüzü lezyonunun, omuz ağrısı nedeni olarak ISS tanısını koymuştur. Baş seviyesi üzerinde aktivite gösteren sporcularda özellikle görülen bir patoloji olan ISS'de kronik süreç sonucu değişik patolojiler dizisi önemli sorunları oluşturmaktadır. Jobe ve Walch'ın tanımladığı
ISS; özellikle posterior omuz ağrısı ile ilgili kliniğe açıklama getirmiştir. Burkhard 1998'de, ${ }^{[52,54]}$ peel back mekanizması ile patolojiyi açıklamıştır. Jobe ve Walch'a göre, ${ }^{[55]}$ artmış dış rotasyon sonucu anterior kapsülde esneme ve postero-superior labrumda mekanik travma esastır. Rotator manşetin ekleme bakan yüzeyindeki yaralanma ile postero-superior glenoiddeki hasarlanmaya, tüberkülüm majus lezyonu da eşlik eder.

\section{Fizyopatoloji}

Postero-superior glenoid ve rotator manşetin ekleme bakan yüzü arasındaki tekrarlayan temas ve mikrotravmatik etki, omuzda yaralanma ve fonksiyon bozukluğuna neden olur. Bu etkileşim normalde sorun oluşturmazken, zorlu hareketler ve tekrarlamalar sonucu omuz mekaniğini değiştirerek patolojik hale gelir. ${ }^{[52,56]}$

Omuz eklemi abduksiyon ve dış rotasyona (ABER) getirildiğinde, normalde humerus başının glenoidde arkaya ve aşağı yer değiştirmesi sonucunda, tüberkülüm majus ve postero-superior glenoid kenar arasında daha az kemiksel temas ve daha fazla hareket açısı olacaktır. Zorlu ve tekrarlı faaliyetlerde, hiperangulasyonun (humerus posterior hareketinin vücut arkasına düşmesi) gelişmesi ile kalıcı değişiklikler gözlenir. ${ }^{[55]}$ Zaman içinde, adaptif kalıcı değişiklikler sorunu daha kompleks hale getirir. ${ }^{[56]}$ Bu değişiklikler; artmış humerus başı ve glenoid retroversiyonu, değişik derecede glenohumeral instabilite, glenohumeral internal rotasyon defisiti (GIRD), skapuler zayıflık veya motor kontrol defisiti (özellikle retraksiyon gücünde zayıflık) ile seyreden skapuler diskinezi (veya skapulatorasik dizkinezi, SICK: sendromu: a-skapular malpozisyon, b-inferior medial kenar belirginliği, c-korakoid malpozisyonu ve 


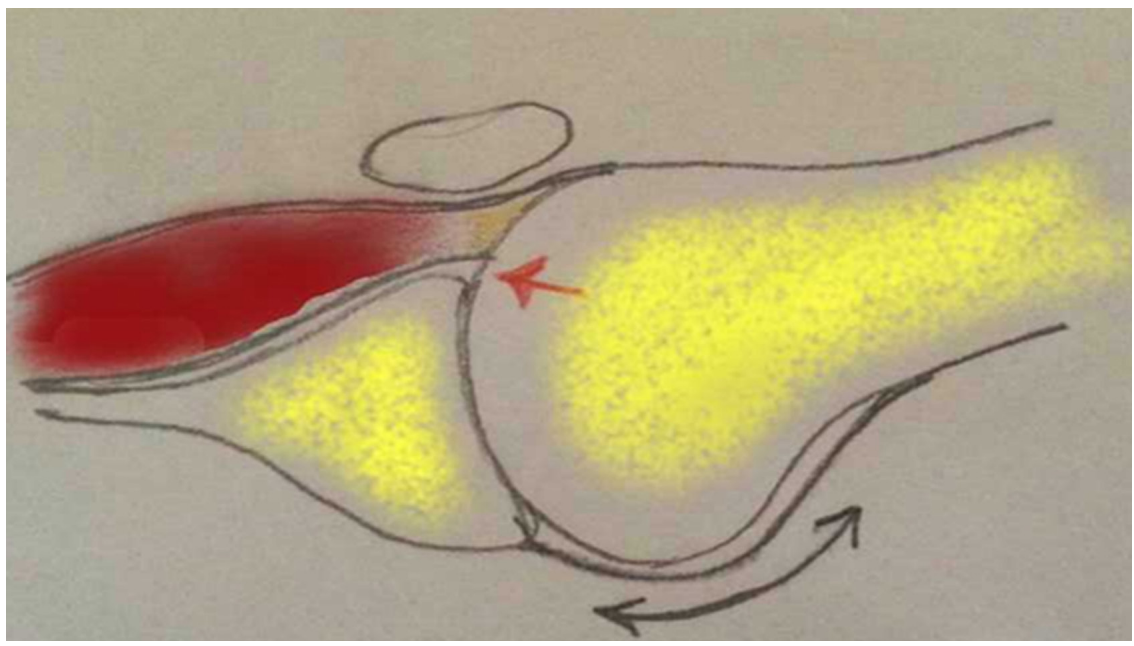

Şekil 12. Humerus başı zorlaması ile kapsülün ön bölümünün esnemeye zorlanması, posterior glenoid ve RC teması.

ağrısı, d-skapula hareketinde malpozisyon) ve eşlik eden rotator manşet zayıflı̆ğdır. ${ }^{[52,57]}$

ISS'de kolun abduksiyon ve dış rotasyonu ile tüberkülüm majus ile glenoid postero-superior arasındaki ilişki ve bu bölgedeki labrum ve rotator manşet (supraspinatus posterior ve infraspinatus anterior lifleri) eklem tarafina bakan yüzde dejenerasyon gözlenir. ${ }^{[55]}$ Ayrıca, humerus başının glenoide teması sonucu oluşan değişiklikler, öpüşen lezyon (kissing lesion) olarak tanımlanmıştır. Bu lezyonda, glenoid ile temas eden tb.majus medialindeki kartilajın dejenerasyonu veya kaybı görülür. ${ }^{[52]}$

ISS mekanizmasının açıklamasına yönelik iki teori vardır. ${ }^{[50,54,58]}$ Bu teoriler şunlardır;

\section{- Andrew}

\section{- Burkhart ve Morgan}

\section{Andrew}

Tekrarlayan abduksiyon-dış rotasyonun omuz dinamik stabilizatörlerinin yorgunluğuna neden olması sonucu öne ve IGHL'e artmış stress yüklenmesiyle, kapsül ön kısmında laksite gelişir (Şekil 12). Humerus başının, posterior ve inferiora translasyonunda azalma sonucu posterior glenoid ve rotator manşete teması iSS'ye yol açar. ${ }^{[50]}$

\section{Burkhart ve Morgan}

Tekrarlayan ABER sonucu posterior omuz kapsülünde sıkılık ve humerus başının superiora translasyonu gelişir. Biseps tutunma noktasına torsiyonel stress ile peel-off mekanizması sonucu Süperior Labrum Anterior Posterior (SLAP) 2 ve psödolaksite gelişimiyle, posterior glenoid ve rotator manşetin temasındaki artmanın ISS'ye yol açtığı öne sürülür..$^{[54]}$ Walch da ${ }^{[55]}$ humerus başı retroversiyonundaki değişmeyi ISS'den sorumlu tutmuştur.

SLAP lezyonlar iSS'ye neden olmaz, ancak biseps ankoruna aşırı torsiyonel stres SLAP patolojisine neden olur. SLAP varlığında humerus başının öne translasyonu 6 mm'ye kadar artarken iGHL zorlanması \%100 artmaktadır. ${ }^{[57]} \mathrm{Bu}$ nedenle SLAP lezyonları bu hasta grubunda araştırılmalıdır.

\section{Klinik ve radyolojik değerlendirme}

iSS, baş üzeri aktivite sonucu gelişen aşırı kullanımın neden olduğu kronik bir patolojidir; sporcuların \%80'inde kendini gösterir. Günlük aktiviteden çok baş üzeri aktivite (teniste servis, voleybolda smaç, beyzbolda firlatma, vb.) sırasında bulgular şikayet nedenidir. Palpasyonla akromiyon posterolateralinde ağrı saptanabilir. Ayırıcı tanıda servikal patolojiler özellikle araştırılmalıdır. ${ }^{[53]}$ Spurling testi bu amaçla oldukça değerlidir.

Radyolojik olarak iç ve dış rotasyonda AP, skapuler Y (skapuler çıkım-outlet), aksiller veya West point pozisyonlarda grafi gereklidir. Aksiller veya West point grafide Bennett lezyonu (posterior kapsülün skapular yapışma yerindeki matür periostal kemiksel oluşumu) görülebilir. Dış rotasyondaki grafide tb.majus lezyonları izlenebilir. Radyolojik olarak tb.majus'ta kistik lezyonlar kronik olgularda gözlenir. ${ }^{[55,57]}$

MR inceleme çok değerlidir. Spesifite ve sensitivitenin \%95'in üzerine olduğu, önemli tanı aracıdır. ${ }^{[56]}$ Özellikle rotator manşet kaslarının eklem tarafındaki yüzeyindeki yırtıkların varlığının değerlendirilmesinde, 
supraspinatus ve infraspinatus tendonu humerus başı yapışma yerlerindeki durumun, kistik değiş̧ikliklerin izlenmesinde MR incelemesi değerlidir. ${ }^{[56]}$ BT ise glenoid ve humerus başı açısının değerlendirilmesinde önemlidir. $^{[55]}$ Artrografi ise invazif yöntemdir ve rotator manşet yırtıklarını değerlendirmede tek-çift kontrast olarak yapılabilirse de MR kadar tanıda yardımcı değildir. [55] Omuz ultrasonu dinamik olarak değerlendirme yapabilmeyi sağlayan pratik ve ucuz bir yöntemdir. Ancak değerlendirmenin başarısı, incelemeyi yapan hekimin tecrübesine bağlıdır. ${ }^{[55]}$

Aktivite sırasında belirginleşen omuz ağrısı; omuzun arkasına lokalizedir. Ağrı, abduksiyon-dış rotasyon hareketinde şiddetlenerek kendini gösterir. Sporcu direkt travma öyküsüne sahip değildir. Günlük yaşamda ağrı yoktur. Şikayetler $\% 80$ baş üzeri aktivitesi olan sporculardadır. Ağrının kronik olması, posteriora lokalizasyonu ve abduksiyon-dış rotasyonda uyarılabilmesi başlıca klinik bulgulardır. Muayenede genellikle eklem hareket kısıtlılığı saptanmaz. Ancak ISS'li hastalarda kol $90^{\circ}$ abduksiyonda iken dış rotasyonda artış, iç rotasyonda 10-15' lik kayıp gözlenir (Şekil 13). ${ }^{[2,57,59]}$

Provokatif testler (Neer, Hawkins, karşı tarafa kolun adduksiyon testi, O"Brain testi) negatiftir. ISS testi (kol $90^{\circ}$ abduksiyonda, maksimum diş rotasyonda eklem arka tarafında ağrı) ve Jobe relokasyon testi pozitiftir. ${ }^{[60-62]}$

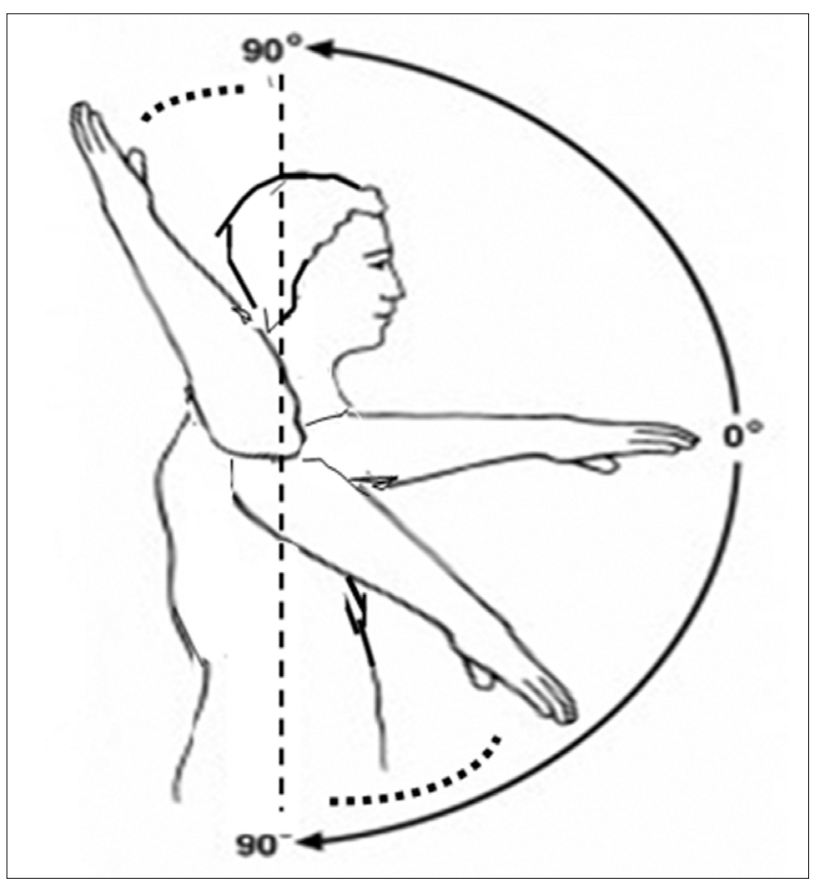

Şekil 13. İç rotasyon da azalmış, dış rotasyonda artmış hareket genişliği.
ISS'ye ait bulgular; kolun abduksiyon ve dış rotasyonunda tüberkülüm majus ile glenoid postero-superior arasındaki ilişki ve bu bölgedeki labrum ve rotator manşetin eklem tarafina bakan yüzde dejenerasyon, humerus başının glenoide teması sonucu oluşan değişikliklerdir (öpüşen lezyon). ${ }^{[55]}$ Bu lezyonda glenoid ile temas eden tb.majus medialindeki kıkırdağın dejenerasyonu veya kaybı görülür. ${ }^{[55]}$ Rotator manşet ve SLAP muayenesi yapılarak, dejenerasyon dikkatle aranmalıdır.

ISS'de Jobe'un tanımladığı evreler ${ }^{[63]}$;

1) omuzda sertlik - rotator manşet ısınma periyodunda uzama,

2) relokasyon testi ile posterior omuz ağrısı. Humerus başının sublüksasyonu ve

3) rehabilitasyona rağmen geçmeyen semptomlar olarak belirtilmiştir.

\section{Tedavi}

\section{Konservatifyöntem}

Tedavide büyük ölçüde yararlanılan yöntemdir. Amaç; hareket serbestliğini korumak, yeterli eklem stabilizasyonu sağlamak ve ağrısız omuz hareketlerinin temin edilmesidir. Öncelikle sportif faaliyete ara verdirilerek eklem istirahati sağlanmalıdır. Rehabilitasyon çalışmalarına başlanarak posterior esnekliğin sağlanması, dinamik stabilizatörlerin düzenlenmesi, rotator manşet kaslarının esnetilmesi hedeflenir. Posterior esnekliğin sağlanması için posterior kapsülü germe ve esnetmeye yönelik sleeper stretch (Şekil 14) ve cross-body stretch (Şekil 15) egsersizleri oldukça yararlıdır. ${ }^{[57,60]}$ Konservatif tedavide uygulanan bu egsersizler iki hafta içinde $\% 90$ semptomatik düzelme sağlar. Konservatif tedavinin yetersizliğinde artroskopik seçici posterior inferior glenohumeral ligamentin kapsüler gevşetilmesi alternatif yöntemdir. ${ }^{[57,60]}$ Tedavide skapular diskineziye yönelik program da çok önemlidir. Kademeli olarak spora dönüş hedeflenmelidir. ${ }^{[60]}$

\section{Cerrahi yöntem}

Artroskopik girişimle, öncelikle eşlik eden diğer patolojiler değerlendirilir. Artroskopi ile kapsüler gevşeklik araştırılır. Skopun yukarıdan glenoid inferioruna rahatıkla geçirilebilmesi ISS'de görülen kapsüler gevşekliğin bir sonucudur ve bu durum, drive-through bulgusu olarak tanımlanmıştır. ${ }^{[64,65]}$ Omuza abduksiyon ve dış rotasyon hareketi verilerek; humerus başının glenoid eklem yüzünün ön kısmına doğru yer değiştirmesi, artroskopik muayenede saptanan diğer bir önemli bulgudur. ${ }^{[64,65]}$ 


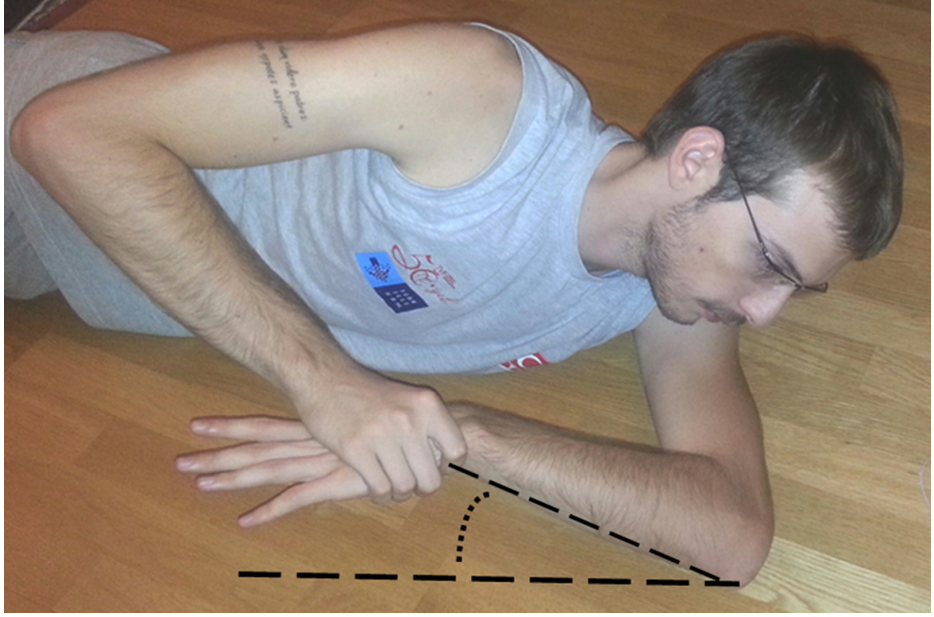

Şekil 14. Sleeper stretch: Yan yatar pozisyonda humerus zemine tam temas ederken; ön kolun iç rotasyon kısıtlılığı diğer kolun kademeli zorlamasıyla açılmaya çalışılır. Ön kolun zemine tam teması sağlanarak arka kapsüler kontraktürü açıcı etki amaçlanır.

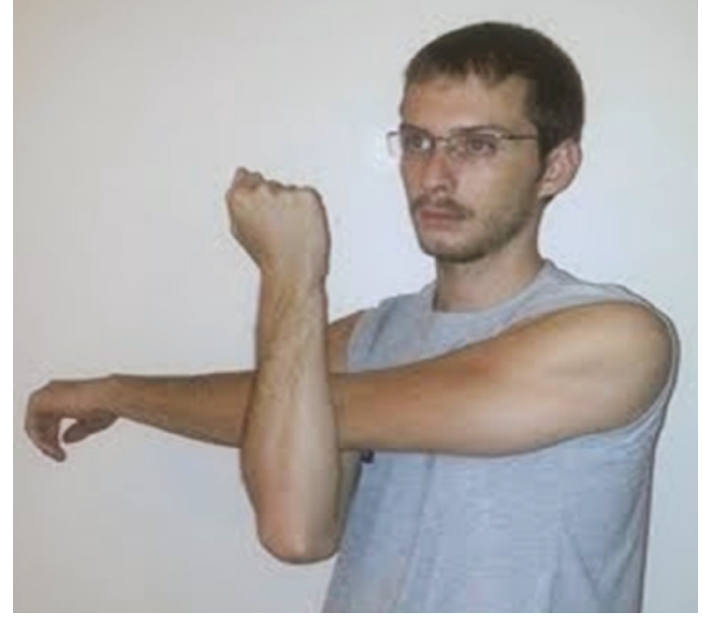

Şekil 15. Cross-body stretch: Hasta taraf; dirsek ekstansiyonda iken vücudun ön tarafından karşı tarafa doğru adduksiyona zorlanır, diğer kolun yardımı ve kademeli zorlama ile arka kapsül esnetilir.
Açık veya artroskopik girişimle kapsülolabral rekonstrüksiyon yapılabilir. Posterior kapsül gevşetilmesi, rotator manşet veya SLAP tamiri, anterior kapsül laksitesinin tedavisi yapılır. Artroskopik termal kapsülorafi ile kapsüler laksite azaltılabilir. ${ }^{[64,65]}$ Rotasyonel osteotomi ile retroversiyon arttırılarak, sıkışmanın azaltılması sağlanabilir. Kullanılan diğer bir yöntem, subakromiyal dekompresyondur. ${ }^{[65]}$

Sporcularda, belirli bir omuz pozisyonunda tekrarlayan zorlamaların yol açtığı bu patolojide tedavi; mevcut yaralanma ve hasarın giderilmesi ve tekrarlayıcı manevraların kısıtlanması ile sağlanır.

\section{KAYNAKLAR}

1. Neer CS 2nd. Anterior acromioplasty for the chronic impingement syndrome in the shoulder: a preliminary report. J Bone Joint Surg Am 1972;54(1):41-50.

2. Neer CS 2nd. Impingement lesions. Clin Orthop Relat Res 1983;(173):70-7.

3. Michener LA, McClure PW, Karduna AR. Anatomical and biomechanical mechanisms of subacromial impingement syndrome. Clin Biomech (Bristol, Avon) 2003;18(5):369-79.

4. Poppen NK, Walker PS. Forces at the glenohumeral joint in abduction. Clin Orthop Relat Res 1978;(135):165-70.

5. Akman S, Küçükkaya M. Subacromial impingement syndrome: pathogenesis, clinical features, and examination methods. Acta Orthop Traumatol Turc 2003;37 Suppl 1:27-34.

6. Watson-Jones R. Fractures and other bone and joint injuries. Baltimore, MD, Williams \& Wilkins, 1940.

7. Bigliani LU, Morrison DS, April EW. The morphology of the acromion and its relationship to rotator cuff tears. Orthop Trans 1986;10:228.
8. Epstein RE, Schweitzer ME, Frieman BG, Fenlin JM Jr, Mitchell DG. Hooked acromion: prevalence on MR images of painful shoulders. Radiology 1993;187(2):479-81.

9. Toivonen DA, Tuite MJ, Orwin JF. Acromial structure and tears of the rotator cuff. J Shoulder Elbow Surg 1995;4(5):376-83.

10. Chambler AF, Bull AM, Reilly P, Amis AA, Emery RJ. Coracoacromial ligament tension in vivo. J Shoulder Elbow Surg 2003;12(4):365-7.

11. Yamamoto N, Muraki T, Sperling JW, Steinmann SP, Itoi E, Cofield RH, An KN. Contact between the coracoacromial arch and the rotator cuff tendons in nonpathologic situations: a cadaveric study. J Shoulder Elbow Surg 2010;19(5):681-7. CrossRef

12. Finnan RP, Crosby LA. Partial-thickness rotator cuff tears. J Shoulder Elbow Surg 2010;19(4):609-16. CrossRef

13. Lohr JF, Uhthoff HK. The microvascular pattern of the supraspinatus tendon. Clin Orthop Relat Res 1990;(254):35-8.

14. Chang WK. Shoulder impingement syndrome. Phys Med Rehabil Clin N Am 2004;15(2):493-510.

15. MacDonald PB, Clark P, Sutherland K. An analysis of the diagnostic accuracy of the Hawkins and Neer subacromial impingement signs. J Shoulder Elbow Surg 2000;9(4):299-301.

16. Park HB, Yokota A, Gill HS, El Rassi G, McFarland EG. Diagnostic accuracy of clinical tests for the different degrees of subacromial impingement syndrome. J Bone Joint Surg Am 2005;87(7):1446-55.

17. Hawkins RJ, Brock RM, Abrams JS, Hobeika P. Acromioplasty for impingement with an intact rotator cuff. J Bone Joint Surg $\mathrm{Br}$ 1988;70(5):795-7.

18. Pappas GP, Blemker SS, Beaulieu CF, McAdams TR, Whalen ST, Gold GE. Invivo anatomy of the Neer and Hawkins sign positions for shoulder impingement. J Shoulder Elbow Surg 2006;15(1):40-9. 
19. Roberts CS, Davila JN, Hushek SG, Tillett ED, Corrigan TM, Magnetic resonance imaging analysis of the subacromial space in the impingement sign positions. J Shoulder Elbow Surg 2002;11(6):595-9.

20. Mair SD, Viola RW, Gill TJ, Briggs KK, Hawkins RJ. Can the impingement test predict outcome after arthroscopic subacromial decompression? J Shoulder Elbow Surg 2004;13(2):150-3

21. Lim JT, Acornley A, Dodenhoff RM. Recovery after arthroscopic subacromial decompression: prognostic value of the subacromial injection test. Arthroscopy 2005;21(6):680-3.

22. Schmitt J, Haake M, Tosch A, Hildebrand R, Deike B, Griss P. Low-energy extracorporeal shock-wave treatment (ESWT) for tendinitis of the supraspinatus. A prospective, randomised study. J Bone Joint Surg Br 2001;83(6):873-6.

23. Speed CA, Richards C, Nichols D, Burnet S, Wies JT, Humphreys $\mathrm{H}$, Hazleman BL. Extracorporeal shock-wave therapy for tendonitis of the rotator cuff. A doubleblind, randomised, controlled trial. J Bone Joint Surg $\mathrm{Br}$ 2002;84(4):509-12.

24. Downing DS, Weinstein A. Ultrasound therapy of subacromial bursitis. A double blind trial. Phys Ther 1986;66(2):194-9.

25. Kromer TO, Tautenhahn UG, de Bie RA, Staal JB, Bastiaenen $\mathrm{CH}$. Effects of physiotherapy in patients with shoulder impingement syndrome: a systematic review of the literature. J Rehabil Med 2009;41(11):870-80. CrossRef

26. Dorrestijn O, Stevens M, Winters JC, van der Meer K, Diercks RL. Conservative or surgical treatment for subacromial impingement syndrome? A systematic review. J Shoulder Elbow Surg 2009;18(4):652-60. CrossRef

27. Gebremariam L, Hay EM, Koes BW, Huisstede BM. Effectiveness of surgical and postsurgical interventions for the subacromial impingement syndrome: a systematic review. Arch Phys Med Rehabil 2011;92(11):1900-13. CrossRef

28. Bang MD, Deyle GD. Comparison of supervised exercise with and without manual physical therapy for patients with shoulder impingement syndrome. J Orthop Sports Phys Ther 2000;30(3):126-37.

29. Conroy DE, Hayes KW. The effect of joint mobilization as a component of comprehensive treatment for primary shoulder impingement syndrome. J Orthop Sports Phys Ther 1998;28(1):3-14.

30. Codsi MJ. The painful shoulder: when to inject and when to refer. Cleve Clin J Med 2007;74(7):473-4, 477-8, 480-2 passim.

31. Lim JT, Acornley A, Dodenhoff RM. Recovery after arthroscopic subacromial decompression: prognostic value of the subacromial injection test. Arthroscopy 2005;21(6):680-3.

32. Karthikeyan S, Kwong HT, Upadhyay PK, Parsons N, Drew SJ, Griffin D. A double-blind randomised controlled study comparing subacromial injection of tenoxicam or methylprednisolone in patients with subacromial impingement. J Bone Joint Surg Br 2010;92(1):77-82. CrossRef

33. van der Sande R, Rinkel WD, Gebremariam L, Hay EM, Koes BW, Huisstede BM. Subacromial impingement syndrome: effectiveness of pharmaceutical interventions-nonsteroidal anti-inflammatory drugs, corticosteroid, or other injections: a systematic review. Arch Phys Med Rehabil 2013;94(5):96176. CrossRef
34. Chin PY, Sperling JW, Cofield RH, Stuart MJ, Crownhart BS. Anterior acromioplasty for the shoulder impingement syndrome: long-term outcome. J Shoulder Elbow Surg 2007;16(6):697-700.

35. Kappe T, Knappe K, Elsharkawi M, Reichel H, Cakir B. Predictive value of preoperative clinical examination for subacromial decompression in impingement syndrome. Knee Surg Sports Traumatol Arthrosc 2013. [Epub ahead of print]

36. Odenbring S, Wagner P, Atroshi I. Longterm outcomes of arthroscopic acromioplasty for chronic shoulder impingement syndrome: a prospective cohort study with a minimum of 12 years' follow-up. Arthroscopy 2008;24(10):1092-8. CrossRef

37. Magaji SA, Singh HP, Pandey RK. Arthroscopic subacromial decompression is effective in selected patients with shoulder impingement syndrome. J Bone Joint Surg $\mathrm{Br}$ 2012;94(8):1086-9. CrossRef

38. Lunsjö K, Bengtsson M, Nordqvist A, Abu-Zidan FM. Patients with shoulder impingement remain satisfied 6 years after arthroscopic subacromial decompression: a prospective study of 46 patients. Acta Orthop 2011;82(6):711-3. CrossRef

39. Biberthaler $\mathrm{P}$, Beirer M, KirchhoffS, Braunstein $\mathrm{V}$, Wiedemann E, Kirchhoff C. Significant benefit for older patients after arthroscopic subacromial decompression: a long-term follow-up study. Int Orthop 2013;37(3):457-62. CrossRef

40. Goldberg BA, Lippitt SB, Matsen FA 3rd. Improvement in comfort and function after cuff repair without acromioplasty. Clin Orthop Relat Res 2001;(390):142-50.

41. McCallister WV, Parsons IM, Titelman RM, Matsen FA 3rd. Open rotator cuff repair without acromioplasty. J Bone Joint Surg Am 2005;87(6):1278-83.

42. Edelson JG, Taitz C. Anatomy of the coraco-acromial arch. Relation to degeneration of the acromion. J Bone Joint Surg Br 1992;74(4):589-94.

43. Donigan JA, Wolf BR. Arthroscopic subacromial decompression: acromioplasty versus bursectomy alone-does it really matter? A systematic review. lowa Orthop J 2011;31:121-6.

44. Levy O, Copeland SA. Regeneration of the coracoacromial ligament after acromioplasty and arthroscopic subacromial decompression. J Shoulder Elbow Surg $2001 ; 10(4): 317-20$

45. Hunt JL, Moore RJ, Krishnan J. The fate of the coracoacromial ligament in arthroscopic acromioplasty: an anatomical study. J Shoulder Elbow Surg 2000; 9(6):491-4.

46. Green A, Griggs S, Labrador D. Anterior acromial anatomy: Relevance to arthroscopic acromioplasty. Arthroscopy 2004;20(10):1050-4.

47. Pillai A, Eranki V, Malal J, Nimon G. Outcomes of open subacromial decompression after failed arthroscopic acromioplasty. ISRN Surg 2012;2012:806843. CrossRef

48. Bennett GE. Elbow and shoulder lesions of baseball players. Am J Surg 1959;98:484-92.

49. Lombardo SJ, Jobe FW, Kerlan RK, Carter VS, Shields CL Jr. Posterior shoulder lesions in throwing athletes. Am J Sports Med 1977;5(3):106-10.

50. Andrews JR, Broussard TS, Carson WG. Arthroscopy of the shoulder in the management of partial tears of the rotator cuff: a preliminary report. Arthroscopy 1985;1(2):117-22. 
51. Jobe FW, Kvitne RS, Giangarra CE. Shoulder pain in the overhand or throwing athlete. The relationship of anterior instability and rotator cuff impimgement. Orthop Rev 1989;18(9):963-75.

52. Jobe FW, Giangarra CE, Kvitne RS, Glousman RE. Anterior capsulolabral reconstruction of the shoulder in athletes in overhand sports. Am J Sports Med 1991;19(5):428-34.

53. Walch G, Liotard JP, Boileau P, Noël E. Postero-superior glenoid impingement. Another impingement of the shoulder. J Radiol 1993;74(1):47-50.

54. Burkhard SS, Morgan CD. Peel-back mechanism: its role in producing and extending posterior type II lesions and its effect on SLAP repair rehabilitation. Arthroscopy 1998;14(6):637-40.

55. Walch G, Boileau P, Noel E, Donel ST. Impingement of the deep surface of the supraspinatus tendon on the posterosuperior glenoid rim: An arthroscopic study. J Shoulder Elbow Surg 1992;1(5):238-45. CrossRef

56. Giaroli EL, Major NM, Higgins LD. MRI of internal impingement of the shoulder. AJR Am J Roentgenol 2005;185(4):925-9.

57. Behrens S, Compas J, Deren ME, Drakos M. Internal impingement. a review on a common cause of shoulder pain in throwers. Phys Sportsmed 2010;38(2):11-8. CrossRef
58. Burkhart SS, Morgan CD, Kibler WB. Shoulder injuries in overhead athletes. The "dead arm" revisited. Clin Sports Med 2000;19(1):125-58.

59. Ruotolo C, Price E, Panchal A. Loss a total arc of motion in collagiate baseball players. J Shoulder Elbow Surg 2006;15(1):67-71.

60. Pujalte GG, Zaslow TL. A practical guide to shoulder injuries in the throwing athlete. J Fam Pract 2013;62(4):175-80.

61. Cheung $S$. Shoulder injuries in the throwing athlete. Orth Sports Med 2011;4:173-84.

62. Reinold MM, Gill TJ. Current concepts in the evaluation and treatment of the shoulder in overhead throwing athletes, part 1: physical characteristics and clinical examination. Sports Health 2010;2(1):39-50.

63. Jobe CM. Superior glenoid impingement. Current Concepts. Clin Orthop Relat Res 1996;(330):98-107.

64. Andrew JR, Dugas JR. Diagnosis and treatment of shoulder injuries in the trowing athlete: the role of thermal-assisted capsuler shrinkage. Instr Course Lect 2001;50:17-21.

65. Dugas JR, Andrews JR. Thermal capsular shrinkage in the throwing athlete. Clin Sports Med 2002;21(4):771-6. 